\title{
Produksi Nasi Instan Berbasis Diversifikasi Pangan Lokal Ubi Ungu Sebagai Pangan Darurat Fungsional
}

\author{
Erwin Setiawan $^{\mathrm{a}, 1^{*}}$, Alpin Hidayatulloh ${ }^{\mathrm{a}, 2}$, Tania Widiastuti ${ }^{\mathrm{a}, 3}$ \\ ${ }^{a}$ Universitas PGRI Semarang, Gedung Pusat Lantai 3, Kampus 1 Jl. Sidodadi Timur 24, Semarang 50124, Indonesia \\ ${ }^{1}$ setiawaner54@gmail.com*; ${ }^{2}$ alpinhidayatulloh6@gmail.com; ${ }^{3}$ taniawidia887@gmail.com \\ * penulis korespondensi
}

\begin{abstract}
Rice consumption in Indonesia is still very high because the majority of Indonesia's population consumes rice as a staple food, this makes Indonesia have to import rice from abroad. In addition, Indonesia is also a country that is prone to natural disasters, limited staples and cooking utensils are the main causes of lack of nutrition during natural disasters. The use of local tuber raw materials as a diversified product into instant rice. The problem formulation method was by collecting several problems that arise from the background and arranged systematically, using an analytical method with analog rice objects from purple sweet potato as instant rice and tries to relate it to the potential in the development of functional emergency food products. Data collection refered to several literatures in the form of research journals, proceedings, and reference books. The author used the method of analysis and problem solving with several stages, namely understanding the concept of the problem by finding keywords, formulating the problem to be discussed, collecting data through literature study, conducting follow-up discussions, parsing the problem formulation using keywords, and finding solutions and drawing conclusions. The purpose of this artikel ilmiah is to present a breakthrough for the manufacture of instant rice made from local tubers as a nutritional fulfillment. The method of analysis uses the analog rice object of purple sweet potato as instant rice and tries to link it with the potential in the development of functional emergency food products. From the results of the exposure it can be concluded that purple tubers can be used as raw material for instant rice and have nutrients that are good for nutritional fulfillment in humans.
\end{abstract}

Keywords: instant rice, local tubers, natural disasters, nutrition

\section{ABSTRAK}

Konsumsi beras di Indonesia masih sangat tinggi karena mayoritas penduduk Indonesia mengkonsumsi beras sebagai makanan pokok, hal tersebut membuat Indonesia harus mengimpor beras dari luar negeri. Selain itu Indonesia juga menjadi negara yang rawan terjadi bencana alam, keterbatasan bahan pokok dan peralatan memasak menjadi penyebab utama kurangnya pemenuhan gizi saat bencana alam. Pemanfaatan bahan baku umbi lokal sebagai produk diversifikasi menjadi beras instan. Penyusunan artikel ilmiah ini bersifat paparan, yaitu dengan menjelaskan Produksi Nasi Instan Berbasis Diversifikasi Pangan Lokal Umbi Ungu Sebagai Pangan Darurat Fungsional. Metode perumusan masalah dengan cara mengumpulkan beberapa masalah yang timbul dari latar belakang serta disusun secara sistematik. Penyusunan perumusan masalah menggunakan metode analisa dengan objek beras analog dari ubi ungu sebagai nasi instan dan mencoba mengaitkan dengan potensi dalam pengembangan produk pangan darurat yang bersifat fungsional. Pengumpulan data merujuk beberapa literatur berupa jurnal penelitian, prosiding, dan buku referensi. Penulis melakukan metode analisis dan pemecahan masalah dengan beberapaa tahapan yaitu memahami konsep permasalahan dengan menemukan kata kunci, merumuskan masalah yang 
akan dibahas, mengumpulkan data melalui studi literatur, melakukan diskusi lanjutan, mengurai rumusan masalah dengan menggunakan kata kunci, serta menemukan solusi dan menarik kesimpulan. Tujuan artikel ilmiah ini untuk memaparkan terobosan untuk pembuatan nasi instan berbahan dasar umbi lokal sebagai pemenuhan gizi. Metode analisa dengan objek beras analog dari ubi ungu sebagai nasi instan dan mencoba mengaitkan dengan potensi dalam pengembangan produk pangan darurat yang bersifat fungsional. Dari hasil pemaparan dapat disimpulkan bahwa ubi ungu bisa dijadikan sebagai bahan baku nasi instan serta memilki zat gizi yang baik untuk pemenuhan gizi pada manusia

Kata Kunci: bencana alam, gizi, nasi instan, umbi lokal

\section{Pendahuluan}

Konsumsi beras di Indonesia sangat tinggi, pada tahun 2004 konsumsi beras di Indonesia mencapai $139 \mathrm{~kg} / \mathrm{kapita} / \mathrm{tahun}$ (Briawan, 2004). Mayoritas penduduk di Indonesia mengkonsumsi beras sebagai makanan pokok. Hal inilah yang membuat Indonesia harus impor beras meskipun Indonesia dikenal sebagai Negara agraris. Untuk menekan laju impor beras perlu diadakan alternative pengganti. Salah satunya yaitu mengganti sumber karbohidrat dengan bahan lain. Berdasarkan ketersediaan bahan baku, bahan lain yang akan digunakan sebagai alternative yaitu ubi ungu.

Ubi Ungu adalah umbi lokal yang memiliki produktivitas tinggi. Pada tahun 2015 produktivitas umbi ungu mencapai 160,53 kuintal/hektar (Badan Pusat Statistika, 2015). Pemanfaatan ubi ungu di Indonesia belum maksimal, Pemanfaatan konsumsinya sebatas direbus saja Sehingga kurang variatif, dan masyarakat kurang tertarik untuk mengonsumsi umbi ungu. Dalam satu ubi ungu berukuran sedang terkandung karbohidrat komplek sebanyak 28 gram. Komponen utama karbohidrat dalam ubi ungu adalah pati, serat pangan (selulosa, hemiselulosa) serta beberapa jenis gula yang larut seperti maltose, sukrosa, fruktosa, dan glukosa (Widodo dan Ginting, 2004). Ubi ungu memiliki umur simpan yang pendek, jika penyimpanannya dalam suhu ruang hanya bisa bertahan sampai 10 hari saja. Jika disimpan terlalu lama akan membuat umbi ungu mengalami penyusutan bobot, pembusukan, dan ditumbuhi Tunas Sehingga menurunkan kualitasnya. (Chrisnasari et al, 2015). Dengan umur simpan yang pendek inilah diperlukan adanya inovasi pengolahan terhadap ubi ungu untuk meningkatkan produktifikatasnya.

Indonesia merupakan negara yang rawan terserang bencana. Indonesia sebagai Negara Maritim dimana ini berarti Indonesia lebih luas lautan jika dibandingkan dengan daratan. Posisi ini membuat Indonesia rawan terancam banjir jika tidak menjaga kebersihan laut dan kebersihan sungai. Dilihat dari letak geografis Indonesia terletak diantara dua benua dan dua samudra yaitu benua Asia dan benua Autralis dan berada diantara samudra Hindia dan Pasifik. Gempa bumi terjadi karena peregerakan lempeng sehingga terjadi tumbukan antar lempeng dan akan mengakibatkan gempa. Indonesia berada diantara Lempeng Australia, Lempeng Eurasia, dan lempeng Pasifik. Karena berada dalam posisi tiga lempeng ini maka Indonesia besar kemungkinan untuk terjadi gempa. Fenomena banjir, gempa bumi, tanah longsor dan letusan gunung berapi merupakan bencana alam yang sering terjadi di Indonesia. Dalam kondisi seperti ini sering terjadi krisis pangan yang mengakibatkan angka kekurangan gizi meningkat di Indonesia. Bencana yang muncul menyebabkan beberapa ancaman salah satunya krisis pangan (Mudrieq, 2014). 
Melihat dari berbagai permasalahan yang ada maka nasi instan dari umbi ungu sebagai pangan darurat fungsional potensial untuk di kembangakan. Nasi merupakan makanan pokok di Indonesia sehingga produk pangan yang akan dikembangkan yaitu nasi instan Dalam keadaan darurat bencana, peralatan dan kondisi semuanya serba terbatas sehingga nasi instan ini lebih efektif dan layak untuk dikembangkan. Umbi ungu merupakan umbi dengan kandungan karabohidrat yang tinggi dengan produktifitas yang tinggi sehingga umbi ungu ini sesuai untuk diolah menjadi beras analog untuk dijadikan sebagai nasi instan yang memiliki kandungan gizi komplek dan tetap mengenyangkan. Selain itu Kandungan serat pangan yang bermanfaat untuk pencernaan dan indeks glikemiknya yang rendah sampai medium, juga merupakan nilai tambah ubijalar sebagai pangan fungsional.

\section{Metode Penelitian}

Penyusunan artikel ilmiah ini bersifat paparan, yaitu dengan menjelaskan Produksi Nasi Instan Berbasis Diversifikasi Pangan Lokal Umbi Ungu Sebagai Pangan Darurat Fungsional. Metode perumusan masalah dengan cara mengumpulkan beberapa masalah yang timbul dari latar belakang serta disusun secara sistematik dengan tujuan untuk memudahkan penulisan artikel ilmiah, agar tidak menyimpang dari permasalahan penting yang dibahas. Penyusunan perumusan masalah menggunakan metode analisa dengan objek beras analog dari ubi ungu sebagai nasi instan dan mencoba mengaitkan dengan potensi dalam pengembangan produk pangan darurat yang bersifat fungsional. Pengumpulan data merujuk beberapa literatur berupa jurnal penelitian dari laman scopus dan sinta, prosiding, dan buku referensi serta penyusunan sumber pustaka dengan bantuan aplikasi Mendeley. Penulis melakukan metode analisis dan pemecahan masalah dengan beberapaa tahapan yaitu memahami konsep permasalahan dengan menemukan kata kunci, merumuskan masalah yang akan dibahas, mengumpulkan data melalui studi literatur, melakukan diskusi lanjutan, mengurai rumusan masalah dengan menggunakan kata kuncinya, serta menemukan solusi dan menarik kesimpulan.

\section{Hasil dan Pembahasan}

Temuan pada artikel ilmiah ini menunjukkan bahwa masalah mendasar ialah kebiasan masyarakat yang sering mengkonsumsi beras, karena mayoritas masyarakat Indonesia menjadikan nasi sebagai makanan pokok. Sehingga mengakibatkan Indonesia harus melakukan impor beras guna mencukupi kebutuhan pangan masyarakat. Oleh karena itu perlu adanya terobosan atau inovasi Pengembangan potensi pangan lokal supaya tidak ketergantungan dengan bahan pokok berupa beras atau nasi. Selain itu Indonesia juga menjadi negara yang sering mengalami bencana alam, disaat kondisi darurat dalam pengungsian yang notobene sangat keterbatasan dalam hal mobilitias maka sangat minim sekali untuk memperhatikan kondisi kesehatan dan gizi para pengungsi. Penanganan gizi dalam kedaruratan bencana sangat penting. Beberapa hal yang menjadi penyebab pentingnya penanganan gizi yaitu keterbatasan dipengungsian, bantuan makanan untuk mempertahankan status gizi, perlu adanya survailens gizi untuk optimalisasi bantuan dan penanganan gizi yang sesuai (Salmayati, Hermansyah and Agussabti, 2016). Maka melihat permasalahan tersebut diciptkan adanya nasi instan berbasis diversifikasi pangan lokal berupa nasi instan ubi jalar ungu. Hal ini di dukung karena Indonesia kaya akan 
sumber karbohidrat lain seperti contohnya umbi-umbian dan pada umumnya belum ada inovasi pemanfaatan ang dilakukan secara optimal.

\subsection{Kandungan Gizi Pada Ubi Jalar Ungu}

Ubi jalar ugu merupakan umbi-umbian lokal yang banyak dijumpai di masyarakat Indonesia. Bahan pangan local ini sering digunakan sebagai bahan pengganti makanna pokok karena bahan pangan ini mengandung karbohidrat yang tinggi (Tabel 3.1).

\section{Tabel 3.1 Kandungan Nilai Gizi Ubi Jalar Ungu}

\begin{tabular}{lc}
\hline \multicolumn{1}{c}{ Parameter Gizi } & Ubi Jalar Ungu \\
\hline Pati (\%) & 22.64 \\
Gula reduksi (\%) & 0,30 \\
Lemak (\%) & 0,94 \\
Protein (\%) & 0,77 \\
Air (\%) & 70,46 \\
Abu (\%) & 0,84 \\
Serat (\%) & 3,00 \\
Vitamin C (mg/100g) & 21,43 \\
Vitamin A (SI)* & - \\
Antosianin $(\mathrm{mg} / 100 \mathrm{~g})$ & 110,51 \\
\hline
\end{tabular}

Sumber : Direktorat Gizi Depkes RI (1981) dalam Direktorat Kacang-kacangan dan UmbiUmbian (2002).

Kelebihan dari ubi jalar ungu ini memiliki antosianin yang tinggi dibandingan dengan ubi jalar pada umumnya yang tidak memilki kandungan antosianin. Selain itu, Antosianin memiliki kemampuan yang tinggi sebagai antioksidan karena kemampuannya menangkap radikal bebas dan menghambat peroksidasi lemak, penyebab utama kerusakan pada sel yang berasosiasi dengan terjadinya penuaan dan penyakit degeneratif (Cevallos-Casals dan Cisneros Zevallos 2002; Suda et al. 2003).

Dengan adanya antosianin pada ubi jalar ungu yang menunjukkan bahwa antosianin mampu digunakan sebagai antimutagenik dan antikarsinogenik (Yamakawa dan Yoshimoto, 2002), dan dapat mencegah gangguan pada fungsi hati, antihipertensi, dan antihiperglikemik. Selain memiliki antosianin yang tinggi, serat pangan yang dimiliki oleh ubi jalar ungu juga menunjukkan nilai gizi yang tinggi yaitu sebesar 3,00 \%. Serat pangan sendiri ialah polisakarida yang tidak dapat dicerna/ dihidrolisis oleh enzim pencernaan manusia dan sampai ke dalam usus besar dalam keadaan utuh (Silalahi 2006). Senyawa pektin, hemiselulosa, dan selulosa merupakan serat pangan yang terdapat pada ubijalar dan berperan dalam menentukan nilai gizinya (Woolfe, 1992). Menurut World Health Organization (WHO) konsumsi serat 25 gram/hari, apabila mengkonsumsi 100 gram ubi jalar ungu maka sudah memenuhi $8 \%$ angka kecukupan asupan tersebut.

\subsection{Analisis Kadar Amilosa}

Pada pati beras padi dan pati ubi jalar ungu memiliki dua kelompok polisakarida yaitu amilosa dan ailopektin. Amilosa sendiri merpakan jenis polisakarida yang tersusun atas 
unit-unit glukosa berantai lurus dengan ikatan 1,4 D-glukopiranosida, sedangkan jenis amilopektin tersusun atas unit yang sama namun terdapat pula percabangan dengan ikatan 1,6 D-glukopiranosida. Dalam hal ini amilopektin merupakan fraksi utama pada pati beras, namaun dalam hal lain kandungan amilosa yang paling menentukan mutu dari nasi yang akan dihasilkan nantinya, serta menentukan sifat fisik lainnya. Perbedaan kadar amilosa pada beras padi umumnya dan pati ubi jalar ungu (Tabel 3.2).

Tabel 3.2 Kandungan Amilosa Beras Padi dan Ubi Jalar Ungu

\begin{tabular}{cccc}
\hline \multirow{2}{*}{ Jenis } & \multicolumn{2}{c}{ Komposisi } & Kadar Amilosa (\%) \\
& Tepung $(\%)$ & Pati $(\%)$ & $20 \%$ \\
Beras Padi & - & - & 10,65 \\
Ubi Jalar Ungu & $100 \%$ & - & 13,90 \\
Ubi Jalar Ungu & $90 \%$ & 10 & 15,56 \\
Ubi Jalar Ungu & $80 \%$ & 20 & 16,40 \\
Ubi Jalar Ungu & $70 \%$ & 30 & 20,39 \\
Ubi Jalar Ungu & $60 \%$ & 40 & Sumber : Handayani., et al, 2016 ; Dianti R.W., 2010
\end{tabular}

Kadar amilosa merupakan suatu parameter yang akan mempengaruhi sifat nasi yang dihasilkan dan akan berkaitan dengan sifat fungsionalnya. Kandungan amilosa akan selalu berbanding terbalik dengan kandungan amilopektin. Ketika kandungan amilosa tinggi maka kandungan amilopektin akan rendah. Berdasarkan tabel 2 Kandungan amilosa beras padi dan ubi jalar ungu. Diperoleh hasil bahwa kandungan amilosa beras analog ubi jalar ungu yaitu berkisar pada 10,65\%-20,39\%. Sedangkan kandungan amilosa beras padi pada umumnya yaitu 20\% (Handayani., et al, 2016 ; Dianti R.W., 2010). Kandungan amilosa pada beras akan berpengaruh pada kelengketan dan keperaan nasi yang dihasilkan. Semakin tinggi kandungan amilosa maka akan semakin pera nasi yang dihasilkan. Adapun klasifikasi kandungan amilosa beras dibedakan menjadi tiga kelompok, yaitu amilosa rendah (12,1\%-20,0\%), kelompok amilosa sedang yaitu (20,0\%-24\%), dan kelompok amilosa tinggi (>25\%) (Juliano,1971). Keperaan dan kadar amilosa akan mempengaruhi daya cerna dari nasi yang dihasilkan. Semakin tinggi kadar amilosa maka akan semakin sulit untuk dicerna. Sedangkan semakin rendah kadar amilosa maka nasi akan semakin mudah dicerna. Hal ini akan berpengaruh pada indeks glikemik jika dikonsumsi. Kadar amilosa yang tinggi akan menyebabkan indeks glikemik yang rendah dan kecernaan nasi akan semakin rendah. Sedangkan kadar amilosa yang rendah akan mengakibatkan indeks glikemik yang tinggi dan kecernaan nasi akan semakin tinggi (Handayani., et al, 2016).

\subsection{Analisis Uji Sensoris}

Sifat Sensoris suatu produk pangan sangat erat kaitannya terhadap daya terima produk dalam masyarakat. Berikut ini adalah sifat sensoris beras analog dari berbagai ubi jalar dengan metode pengujian uji hedonik dapat dilihat pada tabel 3 , dengan skala 1-5. (1= sangat tidak suka, $2=$ tidak suka, $3=$ agak suka, $4=$ suka, 5= sangat suka). 
Tabel 3.3 Hasil Penilaian Hedonik Beras Analog dengan Berbagai Jenis Ubi Jalar Parameter Ubi jalar yang digunakan

\begin{tabular}{cccc} 
& Putih & Kuning & Ungu \\
\hline Warna & $2,07 \pm 0,83$ & $2,63 \pm 0,83$ & $4,50 \pm 0,57$ \\
Aroma & $2,13 \pm 0,68$ & $2,87 \pm 0,82$ & $4,47 \pm 0,63$ \\
Kelengketan & $1,77 \pm 0,63$ & $2,77 \pm 0,92$ & $4,77 \pm 0,55$ \\
Rasa & $1,70 \pm 0,75$ & $2,53 \pm 9,94$ & $4,57 \pm 0,57$ \\
Overall & $2,33 \pm 0,48$ & $3,07 \pm 0,64$ & $4,70 \pm 0,47$ \\
\hline
\end{tabular}

Sumber : Anggraeni Novia., et al, (2016)

Penilaian hedonik beras analog bertujuan untuk membandingkan secara fisik sifat analog dari ubi jalar putih, kuning dan ungu. Pengujian warna beras analog dengan menggunakan bahan ubi jalar yang berbeda memberikan pengaruh warna yang signifikan (Tabel 3.3). Nilai tertinggi ada pada berasa analog ubi ungu yaitu sebesar 4,50 dan niai terendah terdapat pada perlakuan ubi jalar putih yaitu 2,07. Hal ini diduga karena penambahan ubi jalar yang berbeda memberikan pengaruh warna terhadap beras analog sesuai dengan ciri chas warna dari masing-masing jenis ubi sehingga memberikan warna yang disukai oleh konsumen. Menurut Saputra et al, (2014) konsumen akan lebih menyukai produk dengan bentuk yang rapih, bagu dan dalam kondisi yang masih utuh dibandingan dengan produk yang kurang rapid an tidak utuh. Warna merupakan sesuatu yang dapat di terima oleh indra manusia, warna merupakan salah satu faktor yang menentukan diterima atau tidaknya suatu produk. Warna ungu pada beras analog umbi ungu disebabkan oleh kandungan antosianin dari ubi ungu. Menurut Leighton et al, (2010) kandungan antosianin pada ubi jalar berpotensi untuk dijadikan sebagai pewarna alami untuk makanan maupun minuman. Stabilitas antosianin terhadap pengaruh panas dan sinar UV lebih tinggi pada ubi jalar ungu daripada antosianin yang berasal dari strawberry, raspberry, apel serta kedelai hitam. Antosianin adalah metabolit sekunder dari family flavonoid, yang dalam jumlah besar ditemukan dalam buah-buahan dan sayur-sayuran. Antosianin adalah suatu kelas dari senyawa flavonoid, yang secara luas terbagi dalam polifenol tumbuhan. Antosianin pada ubi ungu memiliki perbedaan aktivitas antioksidan yang terletak pada jenis zat warna.

Berdasarkan uji aroma nilai tertinggi ada pada ubi jalar ungu yaitu sebesar 4.47 dan nilai terendah ada pada ubi jalar putih yaitu 2,13. Perbedan jenis ubi jalar ini memberikan pengaruh nyata terhadap berpedaan aroma beras analog yang dihasilkan. Menurut Suwikatmono et al, (2013) perbedaan ubi jalar terhadap bihun berpengaruh terhadap aroma yang dihasilakan. Berdasarkan penelitian Leksrisompong et al, (2012) aroma terbaik pada uji hedonic aneka ubi jalar terdapat pada ubi jalar ungu. Aroma makanan dapat menentukan enak atau tidaknya suatu makanan. Aroma juga amerupakan salah satu indikator yang menjadi penyebab kelezatan suatu produk pangan. Umumnya konsumen akan menyukai bahan pangan yang memiliki aroma yang akhas dengan aroma yang tidak menyimpang dari aroma normal (Winarno, 2004).

Hasil uji kelengketan pada beras analog ubi jalar dengan berbagai jenis memberikan pengaruh yanga berbeda nyata. Nilai tertinggi terdapat pada ubi jalar ungu yaitu 4,77 dan nilai terendah pada ubi jalar putih yaitu sebesar 1,77. Hal ini disebabkan karena kandungan 
protein dalam beras analog ubi jalar ungu yang tinggi. Sifat fungsional protein menentukan atribut hedonik yang dihasilkan. Karakteristik fungsional protein dapat mempengaruhi kualitas dari suatu produk pangan (Pratiwi et al, 2012).

Berdasarkan uji hedonik rasa, penambahan ubi jalar dengan berbagai jenis berpengaruh nyata terhadap rasa. Hasil terbesar pada ubi jalar ungu yaitu 4,57 dan hasil terendah pada ubi jalar putih yaitu 1,70. Perbedaan rasa ini diduga karena pengaruh dari ubi jalar yang ditambahkan berbeda jenis sehingga menghasilkan rasa yang berbeda pula. Cita rasa makanan dipengaruhi oleh komponen-komponen yang terdapat di dalam makanan seperti protein, lemak, dan karbohidrat yang menyusunnya. Uji rasa menggunakan indra pengecap lidah yang kontak dengan indra syaraf perasa (Suryaningrum et al, 2002).

Berdasarkan keseluruhan jika dilihat dari uji hedonik warna, aroma, kelengketan dan rasa beras analog paling disukai oleh panelis yaitu beras analog dengan ubi jalar ungu dengan kadar kesukaan 4,70 dan nilai terendah yaitu ubi jalar putih dengan kadar kesukaan 2.33 .

\subsection{Analisis Indeks Glikemik}

Indeks glikemik adalah angka yang menunjukan potensi peningkatan gula darah yang bersumber dari karbohidrat yang terdapat pada suatu bahan pangan atau tingkatan suatu produk pangan menurut efeknya terhadap kadar glukosa darah.

Tabel 3.4 Indeks Glikemik dan Beban Glikemik Nasi Analog Ubi Jalar Ungu

\begin{tabular}{cccccc}
\hline Sampel & $\begin{array}{c}\text { Indeks } \\
\text { glikemik }\end{array}$ & $\begin{array}{c}\text { Katagori } \\
\text { IG }\end{array}$ & $\begin{array}{c}\text { Karbohid } \\
\text { rat }(\mathrm{g})\end{array}$ & $\begin{array}{c}\text { Beban } \\
\text { glikemik }\end{array}$ & $\begin{array}{c}\text { Kategori } \\
\text { BG }\end{array}$ \\
\hline $\begin{array}{c}\text { Nasi analog ubi } \\
\text { ungu }\end{array}$ & $19,19 \pm 14,05$ & Rendah & 37,59 & 7,21 & Rendah \\
\hline
\end{tabular}

Sumber : Anggraeni Novia., et al, (2016)

Indeks glikemik nasi analog ubi jalar ungu tergolong kedalam IG kategori rendah <55 (Tabel 3.4). Menurut Venn et.al. (2014) bahwa mengkonsumsi pangan IG rendah mampu memperbaiki sensitivitas insulin, menurunkan laju penyerapan glukosa, serta bermanfaat dalam pengendalian glukosa darah sehingga dapat menurunkan risiko komplikasi pada penderita diabetes melitus tipe 2. Beban glikemik beras analog ubi jalar ungu yaitu 7,21 (termasuk kategori BG rendah). Berdasarkan hasil pengambilan gula darah, indeks glikemik nasi analog ubi jalar ungu adalah 19,19 $\pm 14,05$. Penelitian Arif et al. (2013) menunjukkan bahwa beras IR 36 memiliki IG (Indeks Glikemik) sebesar 45. IG (Indeks Glikemik) beras IR 36 lebih tinggi jika dibandingkan IG beras analog ubi jalar ungu. Hal ini disebabkan oleh perbedaan kadar lemak dan protein. Berdasarkan penelitian Purwani et al. (2007) menunjukkan bahwa beras IR 36 memiliki kadar protein sebesar 7,39\% dan kadar lemak sebesar 0,19\%. Menurut Widanagamage et al. (2009) kandungan protein dan lemak dapat mempengaruhi tinggi rendahnya IG (Indeks Glikemik). Semakin tinggi kadar protein dan lemak maka semakin rendah nilai IG (Indeks Glikemik). 


\section{Kesimpulan}

Potensi ubi ungu sebagai bahan baku nasi instan relatif besar dengan didukung adanya studi terkait kandungan serat pangan yang sangat tinggi yaitu 3,00 dibandingkan dengan umbi lokal lainnya, kandungan amilosa ubi ungu (10,65\%-20,39\%) yang mirip dengan beras padi $(20 \%)$. Potensi ini didukung dengan adanya nilai indeks glikemik beras analog dengan ubi jalar ungu yang rendah (<55) dan hasil kesukaan panelis yang lebih dibandingkan beras analog ubi jalar lainnya.

\section{Ucapan Terima Kasih}

Terima Kasih Penulis sampaikan kepada dosen Pembimbing Bapak M. Khoiron Ferdiansyah S.TP.,M.Sc yang sudah membimbing dalam menyelesaikan artikel ilmiah ini. Terima kasih juga penulis sampaikan kepada semua tim yang sudah berpartisipasi dalam menyelesaikan penulisan artikel ilmiah ini sehingga bisa selesai tepat pada waktunya. Kami menyadari masih banyak kekurangan dalam penulisan artikel ilmiah ini dan masih jauh dari kata sempurna, kritik dan saran selalu kami nantikan guna memperbaiki artikel ilmiah menjadi lebih sempurna.

\section{Pustaka}

Anggraeni, N., Darmanto, Y.S., dan Riyadi, P. H. 2016. Pemanfaatan Nanokalsium Tulang IKAN Nila (Oreochromis niloticus) pada beras analog dari berbagai macam ubi jalar (Ipomoea batatas L) Jurnal Aplikasi Teknologi Pangan, 5 (4).

Arif, Abdullah., Agus, Budiyanto., dan Hoerudin. 2013. Nilai indeks glikemik produk pangan dan faktorfaktor yang memengaruhinya. Jurnal Litbang Pertanian. 32 (3): 91-99.

Briawan, D. 2004. "Pengembangan Diversifikasi Pangan Pokok Dalam Rangka Mendukung Ketahanan Pangan Nasional". Tesis Master di Sekoloah Pasca Sarjana IPB. Bogor.

Cevallos-Casals, B.A. and L.A. Cisneros-Zevallos. 2002. Bioactive and functional properties of purple sweet potato (Ipomoea batatas L. Lam). Acta Horticulture 583: 195-203.

Chrisnasari, R., Soesanti, A., \& Askitosari, T. D. (2015). Pengembangan Bisnis Berbasis Ubi Jalar pada Masyarakat Desa Tamiajeng-Trawas, Kabupaten Mojokerto.

Dianti, R. W. (2010). Kajian karakteristik fisikokimia dan sensori beras organik mentik susu dan ir64; pecah kulit dan giling selama penyimpanan

Direktorat Kacang-kacangan dan Umbi-umbian. 2002. Pengenalan Budidaya Talas, Garut, Ganyong, Gembili, Ubi Kelapa, Iles-Iles, Suweg/Acung. Jurnal Direktorat Jenderal Bina Produksi Tanaman Pangan. Jakarta.

Handayani, N. A., Cahyono, H., Arum, W., Sumantri, I., Purwanto, P., \& Soetrisnanto, D. (2016). Kajian Karakteristik Beras Analog Berbahan Dasar Tepung dan Pati Ubi Ungu (Ipomea batatas). Jurnal Aplikasi Teknologi Pangan, 6(1).

Juliano, B.O. 1971. A simplified assay for milded rice amylase. Cereal Science 
Leighton, C.S., Schoenfeldt., And Kruger. 2010. Quantitative descriptive sensory analysis of five different cultivars of sweetpotato to determine sensory and textural profiles. J. Sensory Studies 25: 2-18.

Leksrisompong, P., Whitson., Truong., and Drake. 2012. Sensory attributes and consumer acceptance of sweet potato cultivars with varying flesh colors. Journal of Sensory Studies Issn 0887-8250.

Mudrieq, Sulfitri Hs. (2014). Problematika Krisis Pangan Dunia dan Dampaknya Bagi Indonesia. Jurnal Academica Fisip Untad, 6(2): 1287-1302.

Pratiwi, A. R., Hartayanie, L., dan Tabita, A. 2012. Sifat fungsional protein spirulina platensis. Jurnal Teknologi Pangan. Universitas Katolik Soegijapranata. Semarang.

Purwani, E. Y., Yuliani, S., Indrasari, S. D., Nugraha, S., dan Thahir, R. 2007. Sifat fisikokimia beras dan indeks glikemiknya. Jurnal Teknologi dan Industri Pangan, 18(1).

Pusat Badan Statistik. 2015. http://bps.go.id. Diakses pada tanggal 10 februari 2021 pada pukul 13.00 WIB.

Salmayati, S., Hermansyah, H., \& Agussabti, A. (2016). Kajian penanganan gizi balita pada kondisi kedaruratan bencana banjir di kecamatan sampoiniet kabupaten aceh jaya. Jurnal Kedokteran Syiah Kuala, 16(3): 176-180.

Saputra, J. S. E., A. Tri Winarni., dan E. Nurcahyadewi. 2014. Pengaruh penambahan biomassa serbuk spirulina platensis terhadap sifat fisik, kimia dan sensori pada tablet hisap (Lonzenges). JPHPI.17(3).

Silalahi, Jansen. 2006. Makanan Fungsional. Yogyakarta: Kanisius.

Suda I, Oki T, Masuda M, Kobayashi M, Nishiba Y, Furuta S. 2003. Physiological functionality of purple-fleshed sweet potatoes containing anthocyanins and their utilization in foods-Review. Japan Int Res Center Agr Sci, 37: 167-173.

Suryaningrum, D. T., Murdinah., dan Arifin, M. 2002. Penggunaan kappa-karaginan sebagai bahan penstabil pada pembuatan fish meat loaf dari ikan tongkol (Euthynnus pelamys. L). Jurnal Penelitian Perikanan Indonesia (Edisi Pasca Panen) 8 (6).

Suwikatmono, Adi., G. Himawan., dan J. Kato. 2013. Modifikasi fisik tepung ubi jalar dan aplikasinya dalam pengembangan produk bihun. Jurnal Penelitian. 16: 334-360.

Venn, Bernard., M. Kataoka, and J. Mann. 2014. The use of different reference foods in determining the glycemic index of starchy and non-starchy test foods. Nutrition Journal 13.

Widanagamage, Rahal., S. Ekanayake., and J. Welihinda. 2009. Carbohydrate-rich foods: glycaemic indices and the effect of constituent macronutrients. International Journal of Food Sciences and Nutrition 60: 215-223.

Widodo, y. dan E. Ginting. 2004. Ubi jalar berkadar betakarotein tinggi sebagai sumber vitamin A. Balai Penelitian Tanaman Kacang-Kacangan dan Umbi-Umbian. Malang.

Winarno, F.G. 2004. Kimia Pangan dan Gizi. PT Gramedia. Jakarta.

Woolfe, J.A., 1992. Sweet Potato; An Untapped Food Resource. Cambridge University Press, New York UK., pp 1-39. 
Yamakawa, O. and Yoshimoto, M. 2002. Sweetpotato as food material with physiological functions. Acta Horticulturae, 583: 179-185. 